THE SPIKE AT BENEFIT EXHAUSTION:

LEAVING THE UNEMPLOYMENT SYSTEM OR STARTING A NEW JOB?

\author{
David Card \\ Raj Chetty \\ Andrea Weber \\ Working Paper 12893 \\ http://www.nber.org/papers/w12893 \\ NATIONAL BUREAU OF ECONOMIC RESEARCH \\ 1050 Massachusetts Avenue \\ Cambridge, MA 02138 \\ February 2007
}

We are extremely grateful to Rudolph Winter-Ebmer and Josef Zweimuller for assistance in obtaining the data used in this study. Funding was provided by the Center for Labor Economics at UC Berkeley. The views expressed herein are those of the author(s) and do not necessarily reflect the views of the National Bureau of Economic Research.

(C) 2007 by David Card, Raj Chetty, and Andrea Weber. All rights reserved. Short sections of text, not to exceed two paragraphs, may be quoted without explicit permission provided that full credit, including $\odot$ notice, is given to the source. 
The Spike at Benefit Exhaustion: Leaving the Unemployment System or Starting a New Job? David Card, Raj Chetty, and Andrea Weber

NBER Working Paper No. 12893

February 2007

JEL No. H0,J6,J64,J65

\begin{abstract}
In this paper, we review the literature on the "spike" in unemployment exit rates around benefit exhaustion, and present new evidence based on administrative data for a large sample of job losers in Austria. We find that the way unemployment spells are measured has a large effect on the magnitude of the spike at exhaustion, both in existing studies and in our Austrian data. Spikes are typically much smaller when spell length is defined by the time to next job than when it is defined by the time spent on the unemployment system. In Austria, the exit rate from registered unemployment rises by over $200 \%$ at the expiration of benefits, while the hazard rate of re-employment rises by only $20 \%$. The difference between the two measures arises because many individuals leave the unemployment register immediately after their benefits expire without returning to work. The modest spike in re-employment rates implies that most job seekers do not wait until their UI benefits are exhausted to return to work: fewer than $1 \%$ of jobless spells have an ending date that is manipulated to coincide with the expiration of UI benefits.
\end{abstract}

David Card

Department of Economics

549 Evans Hall, \#3880

UC Berkeley

Berkeley, CA 94720-3880

and NBER

card@econ.berkeley.edu

Raj Chetty

Department of Economics

UC- Berkeley

521 Evans Hall \#3880

Berkeley, CA 94720

and NBER

chetty@econ.berkeley.edu
Andrea Weber

University of California, Berkeley

Department of Economics

549 Evans Hall \#3880

webera@econ.berkeley.edu 
One of the best-known empirical results in public finance and labor economics is the "spike" in the exit rate from unemployment at the expiration of jobless benefits. This sharp surge in the hazard rate is widely interpreted as evidence that recipients are waiting until their benefits run out to return to work. The spike in exit rates has become a leading example of the distortionary effects of unemployment insurance (UI) and social insurance programs more generally (see e.g., Martin Feldstein, 2005).

In this paper, we review the existing literature on unemployment exit rates around benefit exhaustion, and present new evidence using administrative data for a large sample of Austrian job losers. Our main finding is that the way in which the duration of unemployment spells is measured has a large effect on the magnitude of the spike at exhaustion, both in existing studies and in our Austrian data. Spikes are generally smaller when the spell length is measured by the time to next job than when it is defined by the time spent on the unemployment system. In the Austrian data, we find clear evidence of a large spike in the exit rate from registered unemployment at the point of benefit exhaustion, consistent with earlier studies (e.g., Rafael Lalive et. al., 2006). However, the hazard of re-employment rises only slightly at the same point. Even recalls to the previous employer - which account for one-fifth of spell terminations in our data - increase by no more than $20 \%$ at benefit exhaustion.

We conclude that most job seekers in Austria are not waiting to return to work until their UI benefits are exhausted. Rather, a large fraction simply leave the unemployment registry once their benefits end and they are no longer required to register to maintain their eligibility for benefits. This finding underscores the importance of distinguishing between the effects of government programs such as UI on the decision to work vs. their auxiliary effects on the classification of non-working time. ${ }^{1}$ The effect of UI on whether individuals choose to be classified as "unemployed" or "out of the labor force" can be relatively large because it requires little change in actual behavior. The distortionary costs of the program, however, ultimately depend on how UI affects the time spent working. Hence, the spike in unemployment-exit hazards may substantially overstate the degree of moral hazard induced by UI.

The "reporting" effects induced by UI benefits can also lead to biases in the relation between unemployment and the true state of the macroeconomy, particularly in countries where benefits

\footnotetext{
${ }^{1}$ A similar point is made by David Card and W. Craig Riddell (1993) in explaining the much larger divergence between unemployment rates in Canada and the U.S. than between their employment rates.
} 
last indefinitely. As a result, comparisons of unemployment rates across countries may be contaminated by differences in UI systems that affect the definition of unemployment. ${ }^{2}$

\section{A Review of the Existing Literature}

\subsection{The Measurement of Spell Durations and Spikes}

Existing studies of labor market transitions near the point of unemployment benefit exhaustion have used three alternative measures of duration: the length of benefit receipt, the duration of registered unemployment, and the duration of non-employment (time to next job). Although these measures are equivalent in simple theoretical models, in practice there are important differences between them. The duration of benefit receipt is of interest for computing direct program costs. The time to re-employment is more important for analyzing economic efficiency and optimal benefits (e.g. using the reduced-form elasticity approach in Martin Baily (1978) and Raj Chetty (2006)).

To see why distinguishing between these measures matters for economic efficiency, consider an individual who spends $x>T$ weeks in non-employment, where $T$ is the maximum duration of UI benefits. Suppose the individual's search behavior is unresponsive to $T$, but that he automatically drops off the unemployment register at time $T$. In this case, an increase in $T$ will raise the duration of benefit receipt and the duration of unemployment, but have no effect on the duration of joblessness. Note that this policy change has no efficiency cost - since behavior is unchanged, the increase in $T$ constitutes a pure transfer. This example illustrates why focusing on the duration of benefits or registered unemployment can lead to a misleading characterization of the efficiency costs of UI.

The choice of duration measures also determines the type of spikes that can be detected. Since the exit rate from the benefit system is mechanically equal to $100 \%$ at the exhaustion of benefits, studies that use data on the duration of benefits (e.g., Robert Moffitt, 1985; Bruce Meyer, 1990) focus on the pattern of exit rates just prior to benefit exhaustion. In contrast, studies of the duration of registered unemployment or non-employment (time to next job) have

\footnotetext{
${ }^{2}$ Even when unemployment is measured by the number of individuals who report "searching for a job" in a labor force survey (as in the U.S.), the fact that job search is an explici requirement for UI eligibility can affect how many non-workers are classified as unemployed. In particular, the availability of longer UI benefits may have a "mechanical" effect on unemployment if UI recipients feel compelled to report that they are searching for a job.
} 
tended to focus on potential spikes at the point of exhaustion (e.g., Lawrence Katz and Meyer, 1990b, Lalive et. al., 2006). Some studies with relatively coarse timing information combine spikes in the hazard just before and at exhaustion (e.g., Jan van Ours and Milan Vodopivec, 2006).

An important concern in the measurement of spikes is that unemployment exit rates often exhibit irregularities - due to measurement errors or institutional features - that coincide with the timing of benefit exhaustion. As noted by Katz (1985), for example, survey-based spell data often exhibit heaping at exactly 26, 39, and 52 weeks. Exit rates from the UI system may also exhibit bi-weekly or monthly spikes reflecting the periodicity of benefit payments or job search reporting requirements (Dan Black et al., 2003). For this reason, recent studies have attempted to isolate the independent effect of benefit exhaustion by adopting a quasiexperimental design that compares exit rates at a fixed duration for people who are and are not approaching the exhaustion of benefits.

\subsection{Studies Using Data on Unemployment Durations}

Table 1 presents a selective summary of studies that have estimated the spike in unemployment exit rates at or just before benefit exhaustion. The upper panel focuses on studies that use data on the duration of unemployment benefits or registered unemployment, while the lower panel presents studies that use data on duration of non-employment (time to next job). For each study, we have attempted to describe the data sources and research design, and the main findings with respect to spikes just prior to benefit exhaustion and at exhaustion.

Moffit's (1985) seminal study used administrative data on weeks of compensated unemployment (row 1 of Table 1). Examining Kaplan-Meier (KM) plots of the UI leaving rate, Moffitt found that the exit rate from UI rises in the weeks just prior to benefit exhaustion, consistent with the predictions of a simple search model (Dale Mortensen 1977). Meyer (1990) and Katz and Meyer (1990a) extended Moffitt's statistical model and estimated a higher exit rate in the week prior to exhaustion, controlling non-parametrically for "baseline" exit hazards and identifying the exhaustion effect from variation in the potential duration of benefits across individuals (row 2). Katz and Meyer (1990a) note that many UI recipients are eligible for only a small "partial payment" for their last week of benefits, and may fail to pick up their last check for this reason, leading to a spike in exits in the week prior to exhaustion. After 
adjusting for the partial week effect, their net estimate of the increase in the exit hazard in the second-to-last week of eligibility is statistically indistinguishable from 0 .

Card and Phillip Levine (2000) studied the behavior of UI claimants following a temporary benefit extension in New Jersey (row 3). They found a similar spike in exit rates in the 25th week of benefit receipt for people who eligible for 26 or 39 weeks, perhaps reflecting a tendency to return to work after exactly 6 months, irrespective of UI benefits.

Recent studies using administrative data from the unemployment registers of European countries are not limited to examining pre-exhaustion hazards because individuals can remain on the register after benefits are exhausted. A recent example is the study by Lalive et. al. (2006), who analyze exit rates from registered unemployment in Austria (row 4). Using Kaplan-Meier hazard plots, they document a very large spike in the exit rate at the point of benefit exhaustion (30 or 39 weeks), but find no upward trend prior to exhaustion.

\subsection{Studies using Data on Time to Next Job}

Early studies of the duration of non-employment (or time to the next job) used survey data to test for spikes at the point of UI benefit exhaustion. Katz (1985) and Katz and Meyer (1990a) showed that UI recipients in the Panel Study of Income Dynamics exhibit spikes in their probability of returning to work at 26 or 39 weeks - the points at which UI benefits typically run out - whereas non-recipients have much smaller spikes (row 5). In a companion paper, Katz and Meyer (1990b) used administrative data on UI recipients supplemented with survey information on job start dates to fit a competing risks model of recalls and new job starts (row 6). They found a sharp spike in re-employment at the point of exhaustion, although the number of observations at the spike is small $(n=26)$. Subsequent studies by Fallick (1991) and McCall (1997) used samples from the Displaced Worker Surveys in the US and Canada to compare re-employment hazards of UI recipients and non-recipients (rows 7 and 8). Neither of these studies found a bigger spike in re-employment rates of UI recipients at the point of exhaustion.

More recent studies have used administrative data on payrolls combined with unemploy-

ment registry data to examine re-employment hazards. These studies typically adopt a quasi-experimental approach and compare re-employment rates between UI claimants who are exhausting benefits at a specific duration and others who are not. Three of these stud- 
ies use data from Scandinavian countries (Sweden, Norway, and Finland), and in each case find little or no evidence of a rise in re-employment rates at the point of benefit exhaustion (rows $9,10,11$ ). In contrast, a fourth study by van Ours and Vodopivec (2006) finds a large and clearly discernible spike in the re-employment hazard at the point of UI exhaustion for job seekers in Slovenia (row 12). One explanation for the large spike in the Slovenian case emphasized by Vodopivec (1995) - is that UI recipients are working in the informal sector and waiting until their benefits expire to return to the formal sector (where their new job start is measured). Such behavior is presumably less likely in the Scandinavian countries, where the informal sector is small. ${ }^{3}$

\subsection{Summary}

Our reading of the existing literature is that the timing and magnitude of any spike in the hazard rate around benefit exhaustion depends on the measure of spell length used in the analysis. With respect to behavior just prior to exhaustion, there is some evidence of a rise in exits from the unemployment system, but little evidence of a corresponding shift in re-employment rates. A concern with the pattern of exits from the unemployment system is that any over-estimation of the duration of eligibility will generate what appear to be preexhaustion spikes. Moreover, in the U.S. at least, the relatively high fraction of recipients with only a partial benefit payment for their final week could explain some of the rise in exit rates prior to exhaustion. With respect to behavior at the point of exhaustion, some (but not all) of the studies using survey data to measure job starts find evidence of a spike in the re-employment hazard, while most (but not all) of the studies using administrative data on job starts find a relatively smooth hazard. Overall, the literature suggests that spikes in the exit rate around benefit exhaustion are generally smaller when duration is measured as time to next job rather than time unemployed.

\footnotetext{
${ }^{3}$ We have not included in our summary table a study by Jurajda and Tannery (2003) which uses matched UI claims and UI tax records from the State of Pennsylvania to look at job finding and recall behavior. This study finds extremely large spikes in the recall and new job finding hazards at benefit exhaustion (weekly hazard rates on the order of $10 \%$ and $20 \%$, respectively, relative to rates around $1 \%$ per week before exhaustion). A re-examination of their data shows a coding error that leads to some overstatement of the spike at exhaustion, so the true magnitude is unclear. We are grateful to Frederick Tannery for providing his data and programs.
} 


\section{Austrian Data and Institutional Background}

To provide a more direct comparison between the two measures of spell length, we study durations of registered unemployment and time to the next job using a rich data set based on administrative records for Austria. Austria is a particularly interesting country to study because, unlike many other Western European countries, it has relatively low unemployment rates (an average of 4.1\% over the 1993-2004 period) and relatively high rates of job turnover. Alfred Stiglbauer et. al. (2003), for example, show that rates of job creation and job destruction for most sectors are comparable to those in the U.S.

The Austrian unemployment benefit system also shares several features with the U.S. system. In particular, in both Austria and the U.S., claimants establish benefit eligibility for up to a year when they first enter the UI system. People who return to work without exhausting benefits, then become unemployed again within a year can claim their remaining weeks of benefits. Job losers who have worked for 12 months or more in the preceding two years are eligible for benefits that replace approximately $55 \%$ of their previous (after-tax) wage. Individuals who have worked fewer than 36 months in the 5 years prior to filing for UI can receive up to 20 weeks of benefits. Those who have worked for 36 months or more can receive benefits for up to 30 weeks, which we refer to as "extended benefits" (EB).

In addition to unemployment benefits, job losers with sufficiently long tenure are eligible for lump sum severance payments according to a fixed schedule set by the government. Firms outside the construction sector are required to pay workers who are laid off after 3 years of service a severance payment equal to 2 months of their salary. Payments are generally made within one month of the job termination, and are exempt from social security taxes. We analyze the effects of severance payments on search behavior in Card, Chetty, and Weber (2006). In this paper, we focus on the effects of extended UI benefits on the spike at exhaustion. Since there is some overlap in the eligibility thresholds (specifically, for job losers who have worked for only one employer in the past 5 years), we address the potential confounding effect of severance pay using methods described below.

There are two key institutional differences between the unemployment benefit systems in Austria and the U.S.: (1) the absence of any experience rating in the UI tax system, and (2) the availability of a secondary benefit (known as "unemployment assistance") for those who 
have exhausted regular UI. Unemployment assistance is means-tested and pays a lower level of benefits - on average $38 \%$ of the UI benefit level - indefinitely.

A final important feature of the Austrian labor market is the prevalence of temporary layoffs that end in recall to the previous employer. ${ }^{4}$ As we show below, about $22 \%$ of the unemployment spells in our sample ultimately end in recall. ${ }^{5}$ This allows us to test whether the timing of recalls is specifically linked to the exhaustion of UI benefits, as suggested by Katz (1985).

\subsection{Data}

We analyze the effect of benefit expiration on labor market transitions using data from the Austrian social security registry, which covers all workers except civil servants and the selfemployed. The dataset includes daily information on employment and registered unemployment status, as well as total annual earnings at each employer, and various characteristics of workers and their jobs.

Our analysis sample includes all spells of UI associated with job losses between 1981 and 2001, with two key restrictions. First, we limit the sample to involuntary job losers between the ages of 20 and $50 .{ }^{6}$ Second, we include only the subsample of job losers who worked between 33 and 38 months (3 years +/-3 months) in the past five years. This restriction allows us to focus on a relatively homogeneous sample of job losers who are either eligible for 20 or 30 weeks of benefits, depending on whether they worked more or less than 36 months in the past 5 years. The final analysis sample includes 92,969 job losses. Further details on the database and our sample definition are given in the appendix.

There are two measures of unemployment duration that can be constructed in the data. The first is the duration of registered unemployment (the measure used by Lalive et al., 2006). This is defined as the total number of days that an individual is registered with the unemployment agency. Individuals are required to register while they are receiving benefits, and can remain registered once their benefits are exhausted to take advantage of job search assistance services. The second, which we call "time to next job," is the elapsed time from

\footnotetext{
${ }^{4}$ Temporary unemployment with recall is particularly prevalent in seasonal industries like tourism and construction. See Emilia Del Bono and Andrea Weber (2006).

${ }^{5}$ By comparison, Katz and Meyer (1990b) reported that $57 \%$ of the spells in their data ended in recall.

${ }^{6}$ Job quitters face a 28 -day waiting period for UI eligibility. To eliminate them, we drop people who do not take up UI benefits within 28 days of their job loss.
} 
the end of the previous job to the start of the next job. Although over $90 \%$ of job losers are observed working in a new job, some never return to the data set (perhaps because they move to self-employment or leave the labor force), leading to a long tail of censored observations for the time to the next job.

Table 2 summarizes the characteristics of 4 groups of job losers. Columns 1-2 include all involuntary job losers between 20 and 50 years of age. Columns 3-4 include all the individuals in the analysis sample: the subset with 33-38 months of employment in the past 5 years, i.e. those around the extended benefit (EB) eligibility threshold. The remaining columns include the subsets on the left and right side of the extended benefit (EB) eligibility threshold (columns 5-6 and 7-8, respectively).

Relative to the overall population of job losers, those in the analysis sample are younger (29.9 years versus 33.3 ), more likely to be female ( $53 \%$ versus $42 \%$ ), and more likely to be recorded as married (46\% versus 38\%). As expected given the restrictions on months worked, they also have lower total months of work in the past five years and lower job tenure (23.5 months versus 44.4 months). Their annual earnings at the previous job are also about $15 \%$ lower. Despite these differences, their post-layoff outcomes are not very different from those of other job losers. In particular, they have about the same average duration of registered unemployment (4.5 months) and similar probabilities of leaving unemployment within 20 weeks or one year. Moreover, they have about the same probabilities of remaining jobless for 20 or 52 weeks as the overall sample of job losers, and the same probability of being observed at a new job at some time in the sample (94\%). Those who do find a new job have slightly smaller average wage losses than job-finders in the overall sample (-2\% versus $-6 \%)$ and are a little less likely to be recalled to the previous employer. Overall, however, the characteristics of the job losers in our analysis sample are fairly similar to those of the broader set of job losers, suggesting that our empirical results are likely to be representative of the population of job losers in Austria.

Comparisons between job losers with 33-35 months of work in the past 5 years and those with 36-38 month of work suggest that the two groups have similar pre-displacement characteristics, although the latter group is slightly more likely to be female and has slightly longer tenure at the most recent employer. This comparison of observable characteristics gives little indication of selection around the discontinuity, and suggests in particular that employers are 
not systematically altering layoff decisions based on whether an employee is eligible for 20 or 30 weeks of UI.

One significant difference between the $33-35$ and $36-38$ month groups is that $18 \%$ of individuals eligible for EB receive a severance payment upon job loss, whereas none of the individuals who do not qualify for EB get severance pay. This difference arises from the discontinuity in severance pay eligibility at 3 years of job tenure, which coincides with the threshold for EB eligibility for the subsample of people who worked for only one employer in the past 5 years. Job losers in this category ( $18 \%$ of our sample) become eligible for EB at exactly the same point as they become eligible for severance pay. Consequently, any discontinuous change in behavior at 36 months worked is mainly due to EB, but also includes a small effect of severance pay. We show below that our estimates are robust to controlling for the severance pay effect using a "double RD" specification (see also Card, Chetty, and Weber 2006).

\section{Empirical Results}

\subsection{Graphical Analysis}

We begin with a simple graphical analysis to show how unemployment exit and job finding hazards vary over the unemployment spell. Let $h_{t, T}^{U}$ denote the unemployment exit hazard in week $t$ for an individual who is eligible for $T$ weeks of UI benefits. Similarly, let $h_{t, T}^{J}$ denote the re-employment (job-finding) hazard. We compute these rates as the number of failures in week $t$ divided by the size of the risk set at the beginning of the week.

Figure 1a plots $h_{t, 20}^{U}$ and $h_{t, 20}^{J}$, the unemployment exit and re-employment hazards for individuals who are eligible for 20 weeks of UI benefits. Figure $1 \mathrm{~b}$ shows the corresponding series for individuals eligible for 30 weeks of benefits. In both figures, there is a sharp spike in the unemployment exit hazard in the week of benefit exhaustion $(t=T)$, and a relatively high unemployment exit rate in the weeks immediately after exhaustion (consistent with Lalive et al., 2006). The corresponding changes in the job finding hazards, however, are very small.

Next, we study the effect of potential duration on the hazard rate by examining the difference in the hazard rates between individuals eligible for 20 and 30 weeks of UI. Define $d_{t}^{U}=$ $h_{t, 20}^{U}-h_{t, 30}^{U}$ and $d_{t}^{J}=h_{t, 20}^{J}-h_{t, 30}^{J}$. Figure 2 plots $d_{t}^{U}$ and $d_{t}^{J}$. Observe that $d_{t}^{J}$ is positive for all $t<20$, indicating that individuals eligible for 20 weeks of benefits search harder to find a job 
throughout the unemployment spell (anticipating their shorter duration of benefits), and not just at the point when benefits are exhausted. There is a small increase in $d_{t}^{J}$ from week 18 to 22: 20-week eligibles are somewhat more likely to find jobs in those weeks than the 30-week eligibles. Conversely, individuals eligible for 30 weeks of benefits are slightly more likely to find jobs from week 28 to 32 .

These patterns contrast sharply with the corresponding differences in the unemployment exit rates $\left(d_{t}^{U}\right)$, which exhibits sharp spikes at $t=20$ and $t=30$. The hazard rates in both groups remain elevated after their respective exhaustion dates, indicating that individuals are more likely to drop out of the unemployment register in the weeks after their benefits end as well.

In Figures 3 and 4, we distinguish between recalls and new job starts to determine the source of the spike in re-employment hazards. Figure 3 plots the hazard of being recalled to the previous job, the hazard of finding a new job, and the total hazard of re-employment (which equals the sum of the recall and new job start hazards). In constructing this figure, we make the conventional assumption of independent competing risks (e.g., Katz and Meyer, 1990b): the hazard plot for recalls treats new job starts as censored, while the hazard plot for new job starts treats recalls as censored. Figure 3a considers individuals eligible for 20 weeks of benefits, while Figure $3 \mathrm{~b}$ considers those eligible for 30 weeks of benefits. These figures show an elevation in both the new job-finding and recall rates after benefit exhaustion, suggesting that both margins are operative in the modest rise in job-finding hazards evident in Figure 1.

To give a clearer picture of how the potential duration of benefits affects the hazard rates, in Figure 4 we plot the difference in hazards between the 20 -week and 30-week UI groups, as in Figure 2. Figure 4a plots the difference in recall hazards, while Figure 4b plots the difference in new-job finding hazards. The difference in new job start hazards rises around weeks 18-23, and falls around weeks $30-32$, indicating that individuals are somewhat more likely to start a new job in the weeks after benefits expire. The series for recalls exhibits a similar pattern, with a sharper dip after week 30. This figure suggests that recalls are somewhat more likely to be re-timed to coincide with the expiration of UI benefits, consistent with the hypothesis of Katz (1985). 


\subsection{Hazard Model Estimates}

To quantify the size of the spikes in re-employment and unemployment-exit rates, we estimate Cox proportional hazard models that allow for an unrestricted baseline hazard in the duration of search and include a flexible function of time-to-exhaustion. In particular, we estimate models of the following form:

$$
h_{t}=\alpha_{t} \exp (f(T-t)+\delta(T=30)+\gamma X)
$$

where $h_{t}$ denotes the hazard rate in week $t, \alpha_{t}$ denotes the nonparametric "baseline" hazard rate, $X$ denotes a set of covariates, $f(T-t)$ is a function of the time-to- exhaustion, $T-t$, and $\delta$ is a proportional shift in the hazard for people with 30 weeks of eligibility. We censor all spells at 50 weeks to focus on hazards in the year after job loss. We use a spline function for $f$ in order to allow different effects at different weeks, as in Meyer (1990):

$$
\begin{aligned}
f(T-t)=\theta_{0} I(T-t=0)+\theta_{1} I & (T-t \in\{1,2\})+\theta_{2} I(T-t \in\{3,4\})+\ldots \\
& +\theta_{-1} I(T-t \in\{-1,-2\})+\theta_{-2} I(T-t \in\{-3,-4\})+\ldots
\end{aligned}
$$

The $\theta_{j}$ coefficients are identified despite the nonparametric baseline hazard by the relative difference in the hazard rates between the 20 -week and 30 -week eligibility groups at each $t$, as in Figure 2. The identification assumption is that the two groups would have similar hazard rates at each duration in the absence of their differential UI eligibility. Given the similarity of pre-displacement characteristics between people with 33-35 months of employment in the past 5 years and those with 36-38 months (Table 2) we believe this is a plausible assumption. Further evidence on the validity of comparisons between job losers with work experience on either side of the threshold for extended UI benefits is presented in Card, Chetty, and Weber (2006).

The model in (1) can be easily extended to obtain a "regression discontinuity" (RD) estimate of the spike around benefit exhaustion. In particular, (1) can be augmented with a control function $g(W)$, where $W$ represents months of work in the 5 years prior to job loss, to account for variation in the expectation of the unobserved component of the hazard function that may be correlated with EB eligibility. As in other regression discontinuity analyses, the necessary assumption for identification is that $g$ is continuous at $W=36$. Since eligibility for 
30 weeks of benefits jumps discontinuously at $W=36$, the coefficient $\delta$ and the exhaustion spline $f$ remain identified. We present RD estimates of the benefit exhaustion spline after our baseline analysis.

Table 3 reports estimates of the $\exp \left(\theta_{j}\right)$ coefficients for variants of $(1)$. These represent the ratio of the hazard rate in time-to-exhaustion interval $j$ relative to the rate in the first eight weeks of the spell (the omitted time-to-exhaustion interval). ${ }^{7}$ In specifications 1 and 2 , we estimate the model using unemployment duration as the measure of spell length, defining the failure event as exiting the unemployment registry. In specifications 3 and 4 , we measure duration by time to next job, defining the failure event as starting a new job. Specifications 1 and 3 include no controls, while specifications 2 and 4 include the following covariates: age and its square, log wage and its square, gender, "blue collar" status, Austrian nationality, region dummies, industry dummies, and prior firm size. Note that if eligibility class (20 or 30 weeks of UI) is "as good as randomly assigned" the addition of these controls should not affect the point estimates of the models, though it could in principle lead to a gain in precision.

The estimates from specifications 1 and 2 show that the unemployment exit hazard is approximately 2.4 times higher in the week of benefit exhaustion than in the reference period, and remains elevated for the next 8 weeks. In contrast, as shown in columns 3 and 4 , the re-employment hazard is only 1.15 times larger in the week of exhaustion than the reference period, and remains elevated for only 2 weeks post-exhaustion. Despite the differences postexhaustion, the unemployment-exit and re-employment hazards track each other closely prior to exhaustion. In particular, neither hazard shows an increase just prior to exhaustion, and both imply that eligibility for 30 weeks of UI benefits reduces the average exit rate from unemployment by approximately $6 \%$.

Next, we estimate a set of competing risks models for the time to the next job that distinguish between recalls and new job starts under the assumption of competing independent risks, as in Figure 3. The estimates, reported in Table 4, show that the hazard of recall rises by a factor of about 1.2 at benefit exhaustion, and remains about $25 \%$ higher than the reference hazard for up to 4 weeks. The hazard of new job starts rises by a little less at exhaustion (a factor of 1.14) and remains elevated for only the 2 weeks after exhaustion. These results

\footnotetext{
${ }^{7}$ More precisely, the weeks that are more than 12 weeks before benefit exhaustion are omitted from $f(P-t)$. Hence, the baseline hazards correspond to the hazard rates in these weeks, and the hazard ratios that are reported are relative to this baseline.
} 
mirror the finding in Katz and Meyer (1990b) that the hazard of recall shows a somewhat larger spike at benefit exhaustion than the new job finding hazard. However, the magnitudes of both effects are much smaller in Austria than in Katz and Meyer's data for Missouri job losers in the late 1970s.

Robustness Checks. In Table 5, we report estimates of variants of equation (1) to evaluate the robustness of our main results on the spike in unemployment exit rates and re-employment rates. All of these specifications include the control set used in specifications 2 and 4 of Table 3 . In specifications 1 and 2 of Table 5 , we add a third order polynomial in $W$, the number of days worked in the last 5 years, to equation (1) to obtain an RD estimate of the exhaustion spline. As noted above, the addition of this control function should eliminate any minor differences in the expected hazard function between people in our sample who are eligible for extended benefits and those who are not. Reassuringly, this addition has very small effects on the estimated exhaustion spline coefficients for both the unemployment-exit and re-employment hazards.

As noted above, another potential concern in the estimation of (1) is that about one-fifth of individuals eligible for EB also receive severance payments, which can have an independent effect on search behavior and thereby bias the EB estimates. In specifications 3 and 4 of Table 5, we separate the effects of EB and severance pay by adding a third-order polynomial in the number of days worked at the prior employer (the running variable for severance pay eligibility) and an indicator for severance pay to the model. We also include the cubic polynomial in $W$. As we show in Card, Chetty, and Weber (2006), this "double RD" specification identifies the severance pay and EB effects consistently because the two policies depend discontinuously on different running variables. Controlling for severance pay eligibility has a modest effect on the magnitude of the dummy for 30 weeks of UI benefits, but has almost no effect on the estimated exhaustion splines.

The specification in (1) assumes that the difference in potential duration induces a constant difference in the hazard rate $(\delta)$ and a deviation that depends on time to exhaustion. We have estimated more flexible specifications that allow for differences in the time-to-exhaustion splines for people eligible for 20 or 30 weeks of UI. In one variant (columns 5-6 of Table 5), we added an interaction between eligibility for EB and a post-exhaustion dummy $(T-t \leq 0)$. The coefficient on the interaction term indicates that hazards at and after benefit exhaustion 
are slightly higher for the 30-week group, but the estimates of the exhaustion splines for both unemployment-exit and re-employment rates remain essentially unchanged. In a second variant (not reported), we introduced separate exhaustion splines for the 20 -week and 30-week eligibility groups. Again, we find slightly larger spikes in both the unemployment-exit and re-employment rates around the 30 week exhaustion point. However, the unemployment-exit rate exceeds the re-employment rate by a similar factor at 20 and 30 weeks.

Finally, in column 7, we estimate the baseline model for time to next job using an alternative measure of time-to-benefit-exhaustion. In our basic specifications we included only job losers who register with the employment office within 28 days of their last day of work, and measured the duration of nonemployment from the end of last job to the start of the next job. Austrian UI regulations state that the benefit claim period actually begins on the day a claim is filed (rather than being backdated to the date of job loss). This means that the time to benefit exhaustion is shifted relative to the duration of non-employment by the number of days of delay between the date of job loss and the date of claim filing. To see whether the spike in re-employment hazards at benefit exhaustion is sensitive to the measure of time to exhaustion, we re-estimate (1), correcting for late registration in the measure of time-to-benefit-exhaustion. Since over three quarters of the job losers in our sample file for UI within 3 days of losing their job, this adjustment affects a relatively small subsample, and the estimates in column 7 are only slightly larger than those reported in column 4 of Table 3.

In summary, the hazard model estimates show robust evidence of a very large spike in the unemployment exit hazards when benefits expire. The spike in re-employment rates is an order of magnitude smaller, even among recalls to the previous employer.

\subsection{Quantifying the Magnitude of Re-Timing}

How quantitatively important is the re-timing of job starts to coincide with benefit exhaustion in our sample? To answer this question, we use our estimated hazard models to calculate the excess fraction of completed spells of joblessness that end at or within the month after benefit exhaustion, relative to a counterfactual in which there was no spike in re-employment rates during this interval.

About $80 \%$ of jobless spells end prior to benefit exhaustion, and that the average reemployment rate at and just after exhaustion is roughly $4 \%$. Hence, a $20 \%$ higher re- 
employment rate at exhaustion and in the following 4 weeks implies that an extra $0.8 \%$ of spells of joblessness end at or just after the expiration of UI benefits than would do so in the absence of the exhaustion spike. ${ }^{8}$ This calculation suggests that the manipulation of job starts to coincide with benefit exhaustion is quantitatively a less important behavioral response to the provision of UI benefits than the smooth reduction in re-employment hazards that occurs throughout the spell.

Existing studies have focused primarily on the size of the spike in the hazard at exhaustion. In future studies, it would be useful to report a measure of the fraction of spells that are retimed to coincide with benefit exhaustion, as above. We believe such a measure is more useful for assessing the quantitative importance of moral hazard costs due to the re-timing effect.

\section{Conclusions}

Our survey of the existing literature and our empirical analysis of job losers in Austria indicate that the choice of duration measures has an important effect on inferences about the size of the spike in hazards at benefit exhaustion. Previous studies have used three alternative measures of spell duration: the duration of benefit receipt, the duration of registered unemployment, and the time to next job. The spike in exit rates at exhaustion of benefits is particularly large when spells are measured by duration of registered unemployment. Studies that focus on the duration of benefit receipt often find elevated hazards prior to exhaustion. In contrast, most studies that have focused on time to re-employment and used administrative data to measure job starts have found relatively small changes in exit rates at or near benefit exhaustion.

In the Austrian case, we show that the exit rate from registered unemployment rises by over $200 \%$ at the expiration of benefits, while the hazard rate of re-employment rises by only 20\%. This modest spike implies that fewer than $1 \%$ of jobless spells have an ending date that is manipulated to coincide with the end of UI benefits. The difference in spikes between the two measures arises because many individuals leave the unemployment registry once their benefits expire without returning to work.

While our findings for Austria are consistent with existing studies of other countries, we caution that the magnitude of any spike in the re-employment rate will depend on institutional

\footnotetext{
${ }^{8}$ By comparison, a similar calculation based on the estimates reported by Katz and Meyer (1990b) shows that an additional $3.5 \%$ of jobless spells end precisely at the date of UI exhaustion.
} 
factors and labor market conditions that may differ across countries or over time. Some important factors include the availability of post-exhaustion benefits (Michele Pellizzari, forth.), the participation of UI recipients in the uncovered sector (Vodopivec, 1995), and the incentives for firms to cycle workers through temporary unemployment and recall them when their benefits expire (Feldstein, 1976; Katz, 1985). We conclude that the size of the spike in re-employment rates at exhaustion in the current U.S. labor market (and many other labor markets) remains an open question. Further work on estimating these hazards using administrative measures of time to next job would be particularly valuable. 


\section{Appendix A. Sample Definition.}

The Austrian Social Security Database contains employment records for private sector employees, public sector workers who are not classified as permanent civil servants, and the unemployed. The groups for whom information is missing are self employed and civil servants. Based on Austrian national statistics, about $10 \%$ of the labor force were self employed and $7 \%$ were civil servants in 1996. Therefore, we estimate that the Social Security Database covers roughly $85 \%$ of the total workforce.

For each covered job, the database reports the starting and ending date of the job, the identity of the employer, certain characteristics of the job (e.g., industry, occupation), and total earnings. No information is available on hours of work. Earnings are censored at the Social Security contribution limit, but this only affects a small fraction $(2 \%)$ of the observations in our sample. The database also includes starting and ending dates for unemployment insurance (UI) claims, and information on whether an individual is registered with the employment office as looking for work. No information is available on the amount of UI payments actually received. We code an individual as "unemployed" if he or she is receiving UI, or registered as looking for work.

From the database, we extract all terminations from jobs, which had lasted for at least one year, between 1981 and 2001 that were followed by a UI claim and did not result in a retirement claim within the same calendar year $(1,817,221$ terminations). We exclude terminations from jobs in schools, hospitals, and other public sector service industries (4\% of the total) because some of these jobs are fixed term. We eliminate terminations involving people whose age in years is under 20 or over 49 at the time of the job loss ( $8 \%$ of the remaining sample). Further, we drop all terminations with a delay of over 28 days between the job termination date and the start of the UI claim. This restriction eliminates some $9 \%$ job quitters (who face a 4 week waiting period for UI) and leaves us with 1,379,370 observations. Summary characteristics of this sample are presented in columns 1-2 of Table 2. Finally, we focus on individuals, who had worked between 33 and 38 months (3 years plus/minus 3 months) during the last 5 years. The final sample includes 92,969 job losers. Note that individuals can appear in our sample of job losses multiple times. Among individuals included in the sample at least once, we observe a single job loss for $98 \%$.

For the job losses in our sample, we use all available information on employment, unem- 
ployment, and earnings in the Social Security database files for the years 1972 to 2003 . We merge in information on completed education and marital status from the Austrian unemployment registers, which are available from 1987 to 1998. Spell-specific demographic information is available in this file for each unemployment spell, and we use the information in the last recorded unemployment spell for each individual to assign education and marital status. For individuals whose only spell of unemployment occurred before 1987 or after 1998, however, these variables are missing. We can assign information for $66 \%$ of job losses occurring before 1987, and $75 \%$ of job losses after 1998 . 
References

Baily, Martin N. 1978. "Some Aspects of Optimal Unemployment Insurance." Journal of Public Economics, 10: 379-402.

Black, Dan A., Jeffrey A. Smith, Mark C. Berger and Brett J. Noel. 2003. "Is the Threat of Reemployment Services more Effective than the Services Themselves? Evidence from Random Assignment in the UI System." American Economic Review, 93: 1313-1327.

Bratberg, Espen, and Kjell Vaage. 2000. "Spell Durations with Long Unemployment Insurance Periods." Labour Economics, 7(2): 153-180.

Card, David, and W. Craig Riddell. 1995. "Unemployment in Canada and the United States: A Further Analysis," Papers 352, Princeton, Department of Economics - Industrial Relations Sections.

Card, David, and Phillip Levine. 2000. "Extended Benefits and the Duration of UI Spells: Evidence from the New Jersey Extended Benefits Program." Journal of Public Economics, 78: 107-138.

Card, David, Raj Chetty, and Andrea Weber. 2006. "Cash-on-Hand and Competing Models of Intertemporal Behavior: New Evidence from the Labor Market." National Bureau of Economic Research (Cambridge, MA) Working Paper No. 12639.

Carling, Kenneth, Per-Anders Edin, Bertil Holmlund, and Fredrik Jansson. 1996. "Unemployment Duration, Unemployment Benefits, and Labour Market Programmes in Sweden." Journal of Public Economics, 59: 313-334.

Chetty, Raj. 2006. "A General Formula for the Optimal Level of Social Insurance." Journal of Public Economics, 90: 1879-1901.

Del Bono, Emilia, and Andrea Weber. 2006. "Do Wages Compensate for Anticipated Working Time Restrictions? Evidence from Seasonal Employment in Austria." IZA Discussion Papers 2242, Institute for the Study of Labor (IZA).

Fallick, Bruce C. 1991. "Unemployment Insurance and the Rate of Re-Employment of Displaced Workers." The Review of Economics and Statistics, 73: 228-235.

Feldstein, Martin. 1976. "Temporary Layoffs in the Theory of Unemployment." Journal of Political Economy, 84: 937-958.

Feldstein, Martin. 2005. "Rethinking Social Insurance." American Economic Review, 
95: $1-24$.

Jurajda, Stepan and Frederick J. Tannery. 2003. "Unemployment Benefits and Extended Unemployment Benefits in Local Labor Markets." Industrial and Labor Relations Review, 56: 324-348.

Katz, Lawrence. 1986. "Layoffs, Recalls, and the Duration of Unemployment." National Bureau of Economic Research (Cambridge, MA) Working Paper No. 1825.

Katz, Lawrence, and Bruce Meyer. 1990a. "The Impact of the Potential Duration of Unemployment Benefits on the Duration of Unemployment." Journal of Public Economics, 41: $45-72$.

Katz, Lawrence, and Bruce Meyer. 1990b. "Unemployment Insurance, Recall Expectations, and Unemployment." The Quarterly Journal of Economics, 105: 973 -1002.

Kyyra, Tomi, and Virve Ollikainen. 2006. "To Search or Not to Search? The Effects of UI Benefit Extension for the Elderly Unemployed." VATT Discussion Papers 400, Government Institute for Economic Research Helsinki.

Lalive, Rafael, Jan van Ours, and Josef Zweimüller. Forthcoming, 2007. "How Changes in Financial Incentives Affect the Duration of Unemployment." Review of Economic Studies.

McCall, Brian B. 1997. "The Determinants of Full-Time versus Part-Time Reemployment Following Job Displacement." Journal of Labor Economics, 15: 714-734.

Meyer, Bruce D. 1990. "Unemployment Insurance and Unemployment Spells." Econometrica, 58: 757-782.

Moffitt, Robert. 1985. "Unemployment Insurance and the Distribution of Unemployment Spells." Journal of Econometrics, 28: 85-101.

Mortensen, Dale T. 1977. "Unemployment Insurance and Job Search Outcomes." Industrial and Labor Relations Review, 30: 595-612.

Pellizzari, Michele. Forthcoming. "Unemployment Duration and the Interactions Between Unemployment Insurance and Social Assistance." Labour Economics.

Stiglbauer, Alfred, Franz Stahl, Rudolf Winter-Ebmer, and Josef Zweimüller. 2003. "Job Creation and Job Destruction in a Regulated Labor Market: The Case of Austria." Empirica, 30: 127-148.

van Ours, Jan, and Milan Vodopivec. 2006. "How Shortening the Potential Duration 
of Unemployment Benefits Affects the Duration of Unemployment: Evidence from a Natural Experiment." Journal of Labor Economics, 24: 351-378.

van Ours, Jan, and Milan Vodopivec. 2004. "How Changes in Benefits Entitlement Affect Job-Finding: Lessons from the Slovenian 'Experiment'." IZA Discussion Paper 1181, Institute for the Study of Labor (IZA).

Vodopivec, Milan. 1995. "Unemployment Insurance and Duration of Unemployment: Evidence from Slovenia's Transition." Policy Research Working Paper Series 1552, The World Bank. 


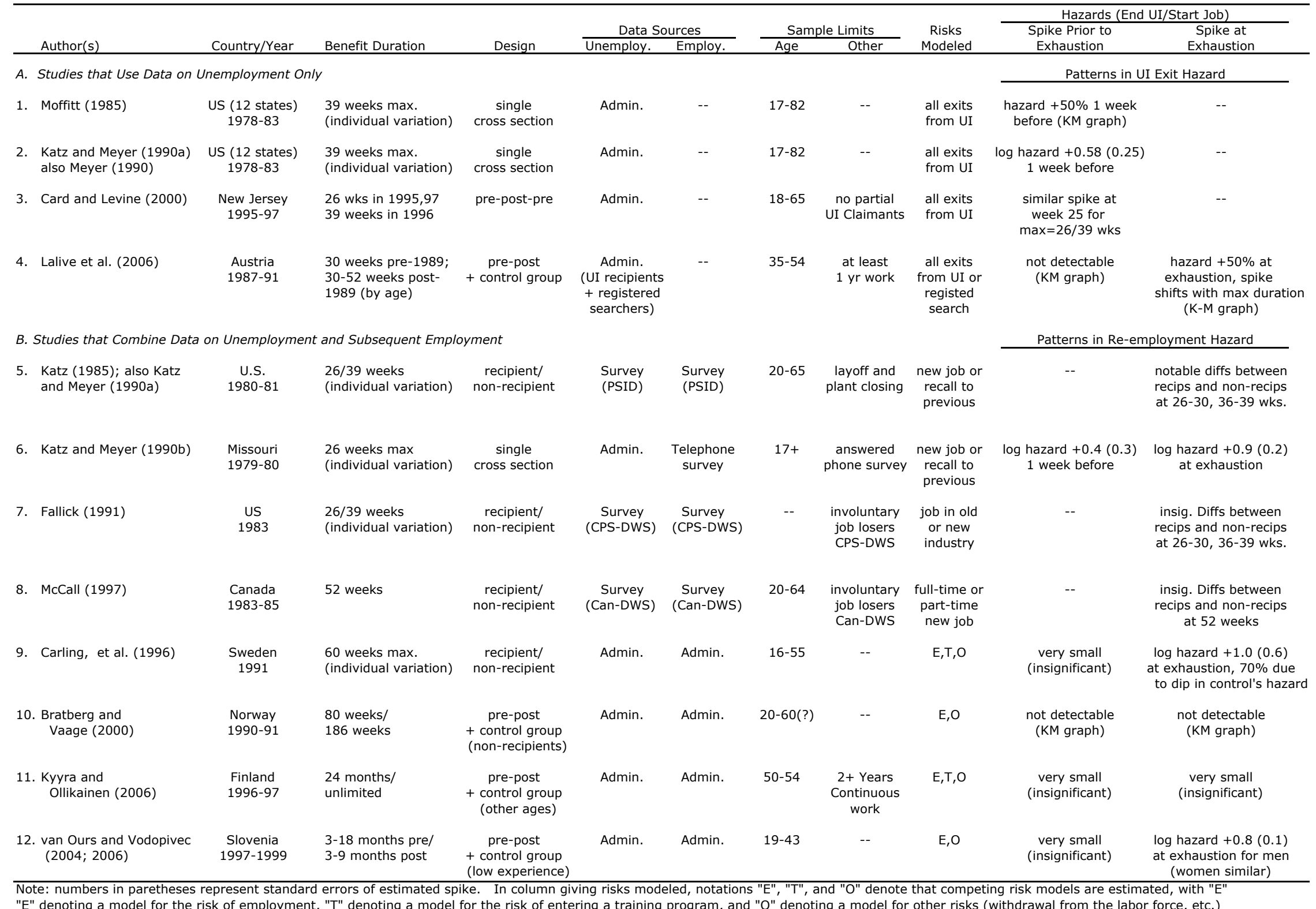

Note: numbers in paretheses represent standard errors of estimated spike. In column giving risks modeled, notations "E", "T", and "O" denote that competing risk models are estimated, with "E"
"E" denoting a model for the risk of employment, "T" denoting a model for the risk of entering a training program, and "O" denoting a model for other risks (withdrawal from the labor force, etc.) 
Table 2: Characteristics of Austrian Job Losers, 1980-2001

\begin{tabular}{|c|c|c|c|c|c|c|c|c|}
\hline & \multicolumn{2}{|c|}{ All Job Losers } & \multicolumn{2}{|c|}{$\begin{array}{c}\text { Analysis Sample: } \\
\text { Job Losers around } \\
\text { EB threshold } \\
\end{array}$} & \multicolumn{2}{|c|}{$\begin{array}{l}\text { Job losers with } 20 \\
\text { weeks UI eligibility }\end{array}$} & \multicolumn{2}{|c|}{$\begin{array}{c}\text { Job losers with } 30 \\
\text { weeks UI } \\
\text { eligibility } \\
\end{array}$} \\
\hline & Mean & Std. Dev. & Mean & Std. Dev. & Mean & Std. Dev. & Mean & Std. Dev. \\
\hline \multicolumn{9}{|l|}{ Worker Characteristics: } \\
\hline Age in Years & 33.33 & 8.26 & 29.85 & 7.76 & 29.54 & 7.84 & 30.13 & 7.68 \\
\hline Female & 0.42 & 0.49 & 0.53 & 0.50 & 0.51 & 0.50 & 0.54 & 0.50 \\
\hline Post-compulsory Schooling & 0.59 & 0.49 & 0.59 & 0.49 & 0.60 & 0.49 & 0.59 & 0.49 \\
\hline Married & 0.38 & 0.48 & 0.46 & 0.50 & 0.47 & 0.50 & 0.45 & 0.50 \\
\hline Austrian Citizen & 0.89 & 0.32 & 0.88 & 0.33 & 0.88 & 0.33 & 0.87 & 0.33 \\
\hline Blue Collar Occupation & 0.64 & 0.48 & 0.61 & 0.49 & 0.62 & 0.48 & 0.60 & 0.49 \\
\hline \multicolumn{9}{|l|}{ Previous Job/Employment: } \\
\hline Months of Tenure & 44.35 & 42.47 & 23.47 & 8.06 & 23.05 & 7.57 & 23.84 & 8.45 \\
\hline Months Worked in Past 5 Years & 47.03 & 13.71 & 35.42 & 1.75 & 33.80 & 0.88 & 36.84 & 0.87 \\
\hline Eligible for Severance Pay & 0.38 & 0.49 & 0.10 & 0.29 & 0.00 & 0.00 & 0.18 & 0.38 \\
\hline Eligible for Extended ( 30 week) UI & 0.78 & 0.41 & 0.53 & 0.50 & 0.00 & 0.00 & 1.00 & 0.00 \\
\hline Previous Wage (Euros/yr) & 18,782 & 9,431 & 16,095 & 7,051 & 15,954 & 6,943 & 16,220 & 7,143 \\
\hline Wage Top-Coded & 0.03 & 0.17 & 0.01 & 0.11 & 0.01 & 0.10 & 0.01 & 0.11 \\
\hline Number of Employees at Firm & 278.70 & 1202.58 & 297.05 & 1357.16 & 252.91 & 1147.92 & 336.06 & 1517.21 \\
\hline \multicolumn{9}{|l|}{ Post-Layoff: } \\
\hline Duration of Unemployment (months) & 4.51 & 8.31 & 4.42 & 7.49 & 4.18 & 7.31 & 4.64 & 7.64 \\
\hline Unemployed $<20$ Weeks & 0.68 & 0.46 & 0.67 & 0.47 & 0.69 & 0.46 & 0.65 & 0.48 \\
\hline Unemployed $<52$ Weeks & 0.94 & 0.23 & 0.95 & 0.23 & 0.95 & 0.22 & 0.94 & 0.23 \\
\hline Duration of Nonemployment (months) & 14.49 & 35.97 & 14.33 & 33.49 & 13.97 & 33.13 & 14.64 & 33.79 \\
\hline Nonemployed $<20$ Weeks & 0.58 & 0.49 & 0.55 & 0.50 & 0.57 & 0.49 & 0.54 & 0.50 \\
\hline Nonemployed $<52$ Weeks & 0.81 & 0.39 & 0.80 & 0.40 & 0.80 & 0.40 & 0.79 & 0.41 \\
\hline Observed in New Job & 0.94 & 0.25 & 0.94 & 0.24 & 0.94 & 0.24 & 0.94 & 0.24 \\
\hline Exhaust Benefits & 0.22 & 0.41 & 0.25 & 0.43 & 0.31 & 0.46 & 0.20 & 0.40 \\
\hline \multicolumn{9}{|l|}{ Among those with New Job: } \\
\hline$\overline{\text { Months to Re-employment }}$ & 7.37 & 15.26 & 8.19 & 16.29 & 8.01 & 16.28 & 8.35 & 16.31 \\
\hline Change in Log Wage & -0.06 & 0.46 & -0.02 & 0.49 & -0.02 & 0.49 & -0.03 & 0.49 \\
\hline Recalled to the Previous Employer & 0.26 & 0.44 & 0.22 & 0.41 & 0.22 & 0.41 & 0.22 & 0.41 \\
\hline
\end{tabular}

Note: Columns 1 and 2 are based on sample of 1,379,370 job losers over the period 1980-2001. Sample includes universe of Austrians job losers (excluding civil service workers) who (1) are between the age 20-50, (2) worked at their previous firm for more than 1 year and (3) took up UI benefits within 28 days of job loss (eliminating job quitters). Columns 3-4 are based on the subsample of 92,969 job losers who worked between 33 and 38 months out of the last 5 years. Columns 5-6 include job losers who worked 33-35 months out of the last 5 years, while columns 7-8 include those who worked 36-38 months. Wages are expressed in real (year 2000) Euros. Unemployment duration is time registered as unemployed; nonemployment duration is time to next job. 
Table 3: Hazard Model Estimates Using Duration of Registered Unemployment and Time to Next Job

\begin{tabular}{|c|c|c|c|c|}
\hline & \multicolumn{2}{|c|}{$\begin{array}{c}\text { Duration Measure }= \\
\text { Registered Unemployment }\end{array}$} & \multicolumn{2}{|c|}{$\begin{array}{l}\text { Duration Measure= } \\
\text { Time to Next Job }\end{array}$} \\
\hline & No Controls & Controls & No Controls & Controls \\
\hline \multicolumn{5}{|l|}{ Pre-exhaustion: } \\
\hline 9-12 weeks before & $\begin{array}{c}0.978 \\
(0.019)\end{array}$ & $\begin{array}{l}0.970 \\
(0.020)\end{array}$ & $\begin{array}{c}0.999 \\
(0.021)\end{array}$ & $\begin{array}{c}1.002 \\
(0.022)\end{array}$ \\
\hline 5-8 weeks before & $\begin{array}{c}1.018 \\
(0.022)\end{array}$ & $\begin{array}{c}1.018 \\
(0.023)\end{array}$ & $\begin{array}{c}1.010 \\
(0.023)\end{array}$ & $\begin{array}{c}1.014 \\
(0.024)\end{array}$ \\
\hline 3-4 weeks before & $\begin{array}{c}1.054 \\
(0.033)\end{array}$ & $\begin{array}{c}1.070 \\
(0.035)\end{array}$ & $\begin{array}{c}1.051 \\
(0.035)\end{array}$ & $\begin{array}{c}1.042 \\
(0.036)\end{array}$ \\
\hline 1-2 weeks before & $\begin{array}{c}1.045 \\
(0.038)\end{array}$ & $\begin{array}{c}1.042 \\
(0.040)\end{array}$ & $\begin{array}{c}1.007 \\
(0.039)\end{array}$ & $\begin{array}{c}1.027 \\
(0.042)\end{array}$ \\
\hline At exhaustion & $\begin{array}{c}\mathbf{2 . 4 0 4} \\
(0.093)\end{array}$ & $\begin{array}{c}2.373 \\
(0.097)\end{array}$ & $\begin{array}{c}1.150 \\
(0.059)\end{array}$ & $\begin{array}{c}1.148 \\
(0.062)\end{array}$ \\
\hline $\begin{array}{l}\text { Post-exhaustion: } \\
\text { 1-2 weeks after }\end{array}$ & $\begin{array}{c}1.478 \\
(0.056)\end{array}$ & $\begin{array}{c}1.455 \\
(0.058)\end{array}$ & $\begin{array}{c}1.199 \\
(0.048)\end{array}$ & $\begin{array}{c}1.187 \\
(0.050)\end{array}$ \\
\hline 3-4 weeks after & $\begin{array}{c}1.369 \\
(0.062)\end{array}$ & $\begin{array}{c}1.375 \\
(0.066)\end{array}$ & $\begin{array}{c}1.035 \\
(0.049)\end{array}$ & $\begin{array}{c}1.062 \\
(0.053)\end{array}$ \\
\hline 5-8 weeks after & $\begin{array}{c}1.226 \\
(0.050)\end{array}$ & $\begin{array}{c}1.224 \\
(0.053)\end{array}$ & $\begin{array}{c}1.009 \\
(0.044)\end{array}$ & $\begin{array}{c}1.012 \\
(0.046)\end{array}$ \\
\hline 9-12 weeks after & $\begin{array}{c}1.165 \\
(0.053)\end{array}$ & $\begin{array}{c}1.147 \\
(0.055)\end{array}$ & $\begin{array}{c}0.929 \\
(0.046)\end{array}$ & $\begin{array}{c}0.927 \\
(0.048)\end{array}$ \\
\hline$>12$ weeks after & $\begin{array}{c}0.958 \\
(0.052)\end{array}$ & $\begin{array}{c}0.967 \\
(0.055)\end{array}$ & $\begin{array}{c}0.772 \\
(0.044)\end{array}$ & $\begin{array}{c}0.782 \\
(0.047)\end{array}$ \\
\hline $\begin{array}{c}\text { Dummy for } 30 \\
\text { weeks of UI (EB) }\end{array}$ & $\begin{array}{c}0.932 \\
(0.010) \\
\end{array}$ & $\begin{array}{c}0.954 \\
(0.011) \\
\end{array}$ & $\begin{array}{c}0.923 \\
(0.011) \\
\end{array}$ & $\begin{array}{c}0.950 \\
(0.012) \\
\end{array}$ \\
\hline
\end{tabular}

Note: estimates (with standard errors in parentheses) are hazard ratios relative to omitted group. Omitted group for exhaustion spline is $>12$ weeks before exhaustion. All models include unrestricted baseline hazard for duration (in weeks). Models in columns 2 and 4 include the following covariates: age and its square, log wage and its square, gender, "blue collar" status, Austrian nationality, region dummies, industry dummies, and prior firm size. 
Table 4: Hazard Model Estimates For Competing Risks of Recall to Previous Employer and Start of New Job

\begin{tabular}{|c|c|c|c|c|}
\hline & \multicolumn{2}{|c|}{ Recall to Previous Employer } & \multicolumn{2}{|c|}{ Start New Job } \\
\hline & No Controls & Controls & No Controls & Controls \\
\hline \multicolumn{5}{|l|}{ Pre-exhaustion: } \\
\hline 9-12 weeks before & $\begin{array}{r}1.001 \\
(0.041)\end{array}$ & $\begin{array}{r}1.021 \\
(0.043)\end{array}$ & $\begin{array}{r}0.996 \\
(0.025)\end{array}$ & $\begin{array}{r}0.994 \\
(0.026)\end{array}$ \\
\hline 5-8 weeks before & $\begin{array}{r}1.035 \\
(0.046)\end{array}$ & $\begin{array}{r}1.056 \\
(0.049)\end{array}$ & $\begin{array}{r}1.001 \\
(0.027)\end{array}$ & $\begin{array}{r}1.000 \\
(0.028)\end{array}$ \\
\hline 3-4 weeks before & $\begin{array}{r}1.035 \\
(0.073)\end{array}$ & $\begin{array}{r}1.041 \\
(0.076)\end{array}$ & $\begin{array}{r}1.048 \\
(0.040)\end{array}$ & $\begin{array}{r}1.037 \\
(0.041)\end{array}$ \\
\hline 1-2 weeks before & $\begin{array}{r}0.954 \\
(0.077)\end{array}$ & $\begin{array}{r}1.007 \\
(0.085)\end{array}$ & $\begin{array}{r}1.023 \\
(0.045)\end{array}$ & $\begin{array}{r}1.035 \\
(0.048)\end{array}$ \\
\hline At exhaustion & $\begin{array}{r}1.188 \\
(0.129)\end{array}$ & $\begin{array}{r}1.231 \\
(0.138)\end{array}$ & $\begin{array}{r}1.140 \\
(0.066)\end{array}$ & $\begin{array}{r}1.124 \\
(0.069)\end{array}$ \\
\hline $\begin{array}{l}\text { Post-exhaustion: } \\
\text { 1-2 weeks after }\end{array}$ & $\begin{array}{r}1.265 \\
(0.105)\end{array}$ & $\begin{array}{r}1.321 \\
(0.115)\end{array}$ & $\begin{array}{r}1.172 \\
(0.054)\end{array}$ & $\begin{array}{r}1.144 \\
(0.055)\end{array}$ \\
\hline 3-4 weeks after & $\begin{array}{r}1.144 \\
(0.125)\end{array}$ & $\begin{array}{r}1.231 \\
(0.140)\end{array}$ & $\begin{array}{r}1.016 \\
(0.054)\end{array}$ & $\begin{array}{r}1.026 \\
(0.058)\end{array}$ \\
\hline 5-8 weeks after & $\begin{array}{r}0.841 \\
(0.082)\end{array}$ & $\begin{array}{r}0.905 \\
(0.093)\end{array}$ & $\begin{array}{r}1.046 \\
(0.051)\end{array}$ & $\begin{array}{r}1.029 \\
(0.053)\end{array}$ \\
\hline 9-12 weeks after & $\begin{array}{r}0.748 \\
(0.085)\end{array}$ & $\begin{array}{r}0.845 \\
(0.101)\end{array}$ & $\begin{array}{r}0.970 \\
(0.054)\end{array}$ & $\begin{array}{r}0.940 \\
(0.055)\end{array}$ \\
\hline$>12$ weeks after & $\begin{array}{r}0.518 \\
(0.069)\end{array}$ & $\begin{array}{r}0.580 \\
(0.082)\end{array}$ & $\begin{array}{r}0.823 \\
(0.052)\end{array}$ & $\begin{array}{r}0.813 \\
(0.054)\end{array}$ \\
\hline $\begin{array}{r}\text { Dummy for } 30 \\
\text { weeks of UI (EB) }\end{array}$ & $\begin{array}{r}0.917 \\
(0.024) \\
\end{array}$ & $\begin{array}{r}0.970 \\
(0.027) \\
\end{array}$ & $\begin{array}{r}0.925 \\
(0.013) \\
\end{array}$ & $\begin{array}{r}0.943 \\
(0.014) \\
\end{array}$ \\
\hline
\end{tabular}

Note: estimates (with standard errors in parentheses) are hazard ratios relative to omitted group. Omitted group for exhaustion spline is $>12$ weeks before exhaustion. All models include unrestricted baseline hazard for duration (in weeks). Models in columns 2 and 4 also include covariates listed in notes to Table 3. All models measure spell length as time to next job. 
Table 5: Robustness Checks

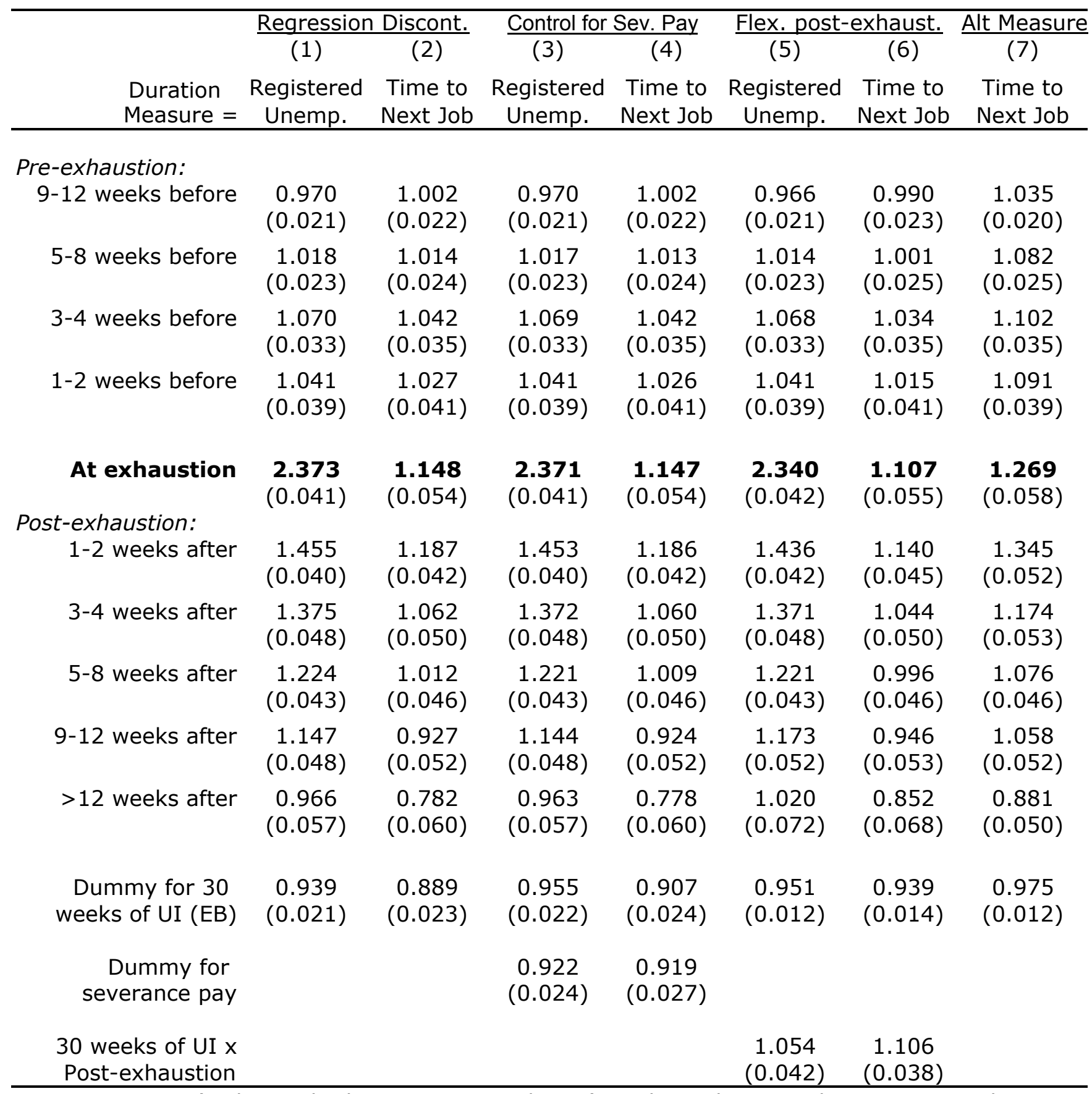

Note: estimates (with standard errors in parentheses) are hazard ratios relative to omitted group. Omitted group for exhaustion spline is $>12$ weeks before exhaustion. All models include unrestricted baseline hazard for duration (in weeks) and individual covariates listed in notes to Table 3. Specifications 1 and 2 include a cubic polynomial in the number of days worked in the last 5 years. Specifications 3 and 4 include a cubic polynomial in the number of days worked in the last 5 years and a cubic polynomial in the days of tenure on the last job. Specifications 5 and 6 include an interaction term between 30 weeks UI eligibility and a post-exhaustion dummy. Specification 7 uses an alternative definition of time-to-exhaustion, as explained in the text. 
Figure 1a

Job Finding vs. Unemployment Exit Hazards: 20 Week UI

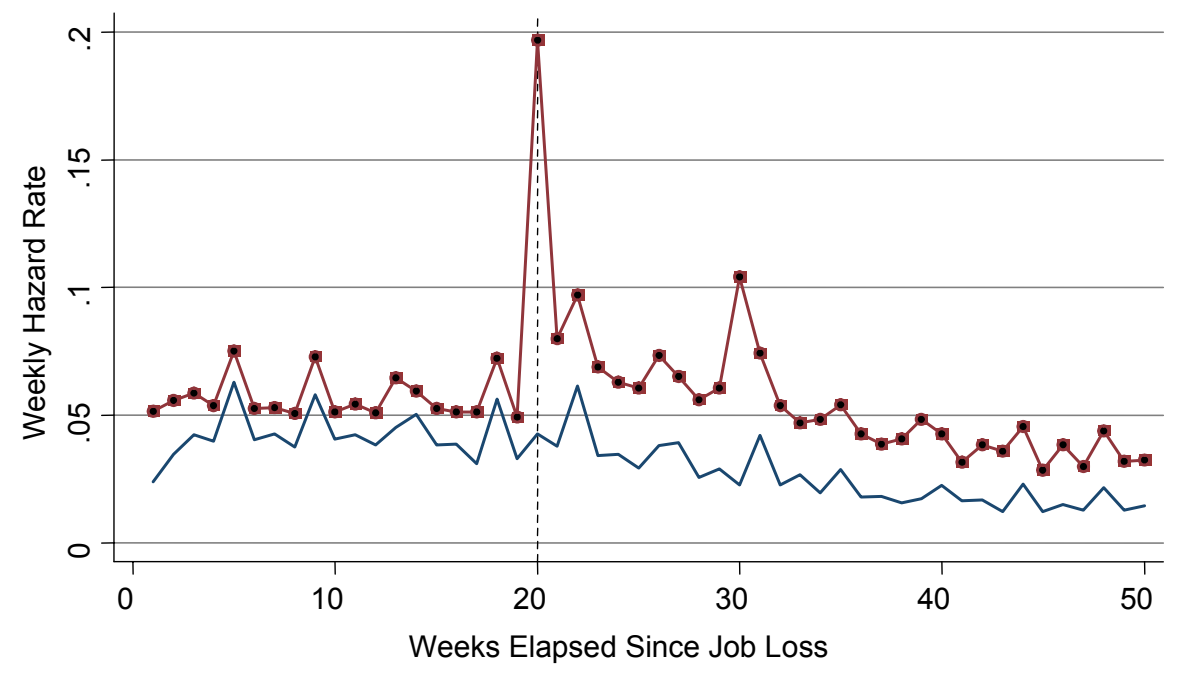

Job Finding Hazards $\longrightarrow$ Unemp Exit Hazards

Figure $1 \mathrm{~b}$

Job Finding vs. Unemployment Exit Hazards: 30 Week UI

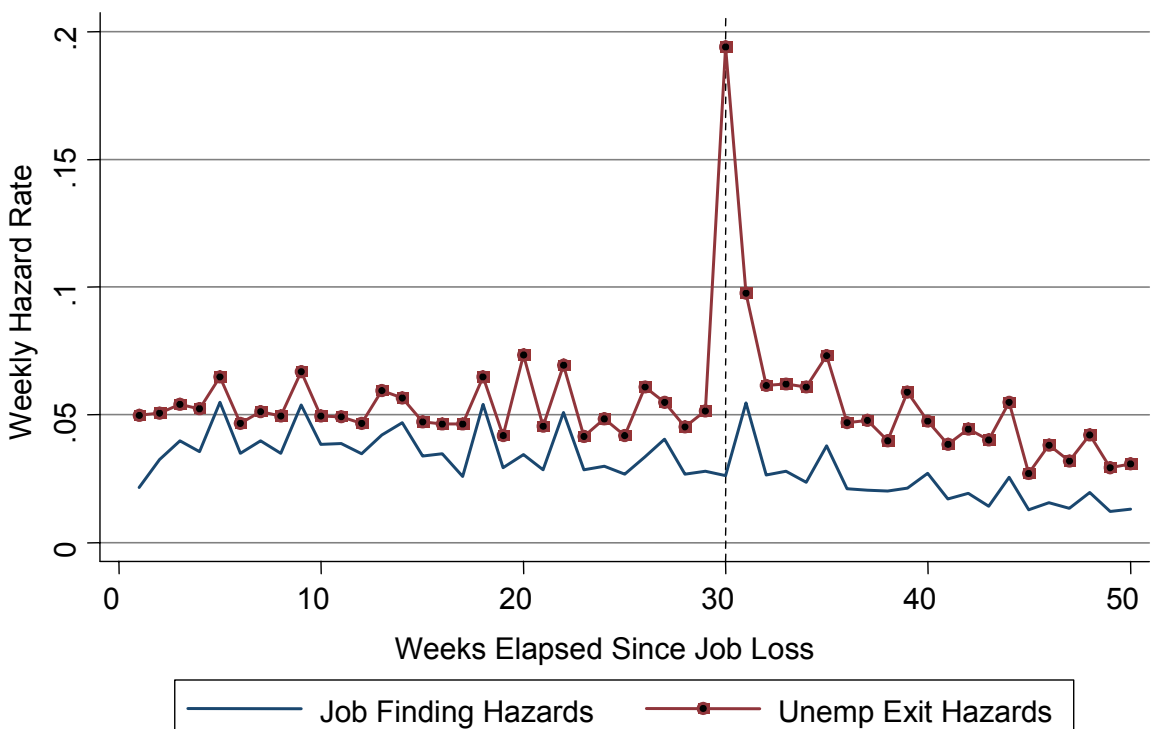

NOTE-These figures plot weekly unemployment-exit hazards and re-employment (job-finding) hazards. Sample in Figure 1a includes all individuals eligible for 20 weeks of $\mathrm{UI}$ benefits (individuals who have between 33 and 35 months of work experience in the past 5 years). Sample in Figure 1a includes all individuals eligible for 30 weeks of UI benefits (individuals who have between 36 and 38 months of work experience in the past 5 years). 
Figure 2

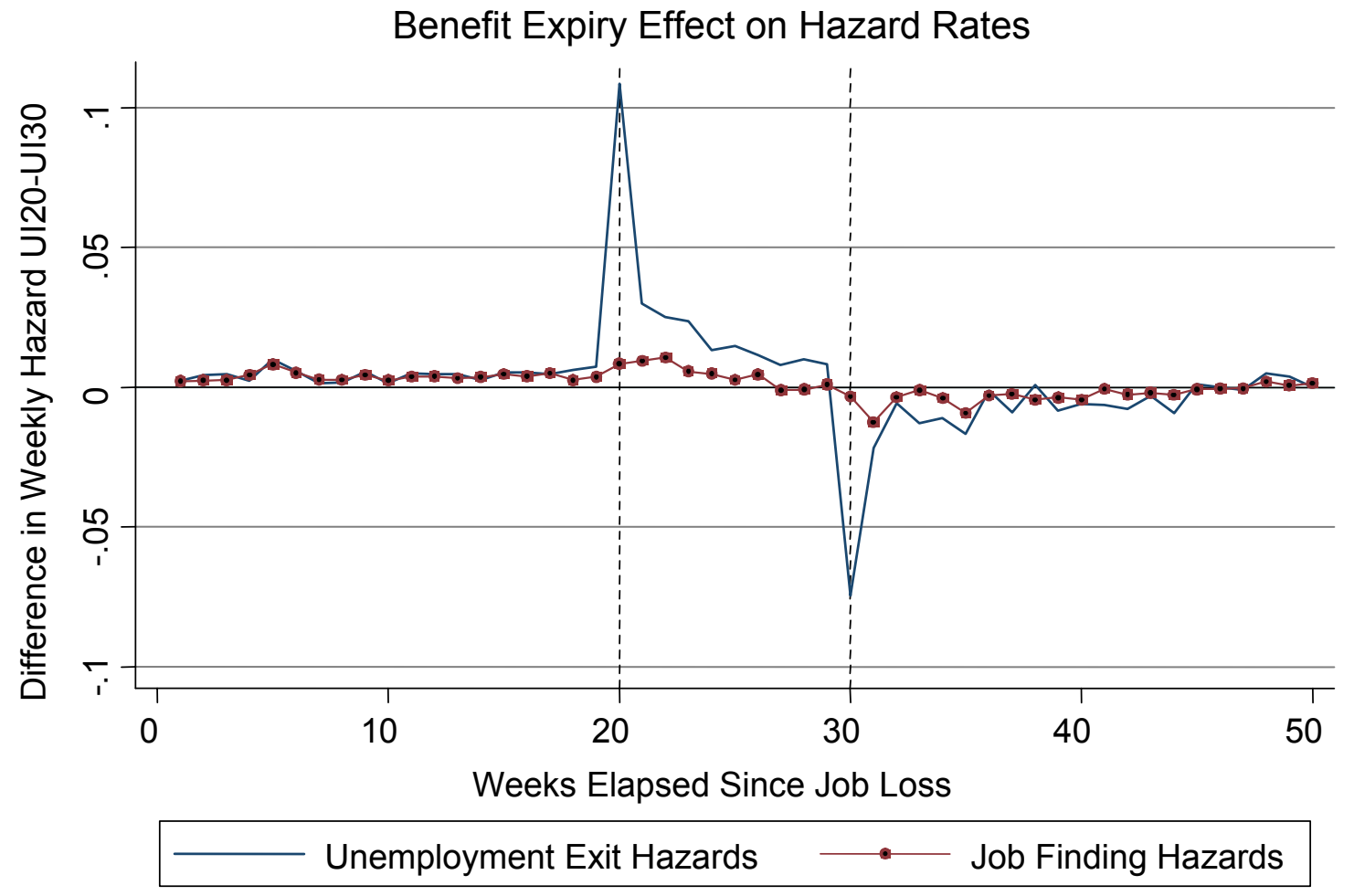

NOTE-This figure plots the difference in weekly hazards between the group of individuals eligible for 20 weeks of $\mathrm{UI}$ benefits and 30 weeks of $\mathrm{UI}$ benefits. The unemployment exit hazard series is the difference between the unemployment exit hazards plotted in Figures $1 \mathrm{a}$ and $1 \mathrm{~b}$. The job-finding hazard series is the difference between the job-finding hazards plotted in Figures $1 \mathrm{a}$ and $1 \mathrm{~b}$. 
Figure $3 a$

Reemployment Hazards -- Recalls vs. New Jobs: 20 Week UI
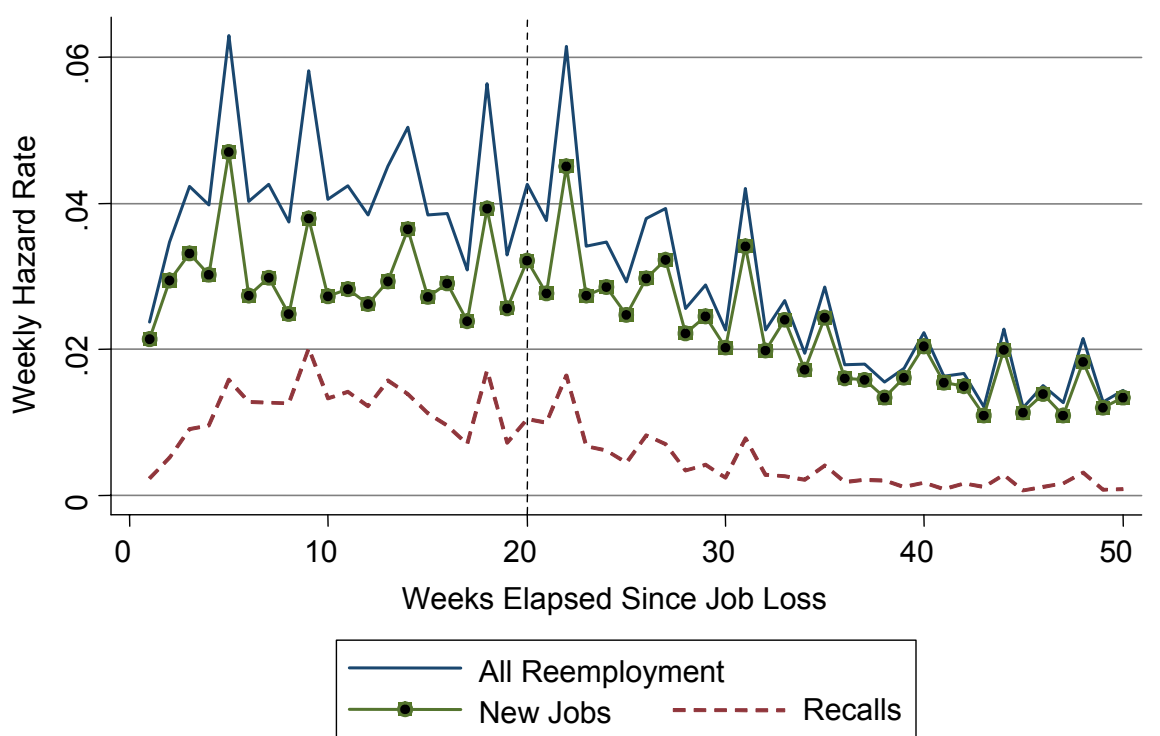

Figure $3 b$

Reemployment Hazards -- Recalls vs New Jobs: 30 Week UI

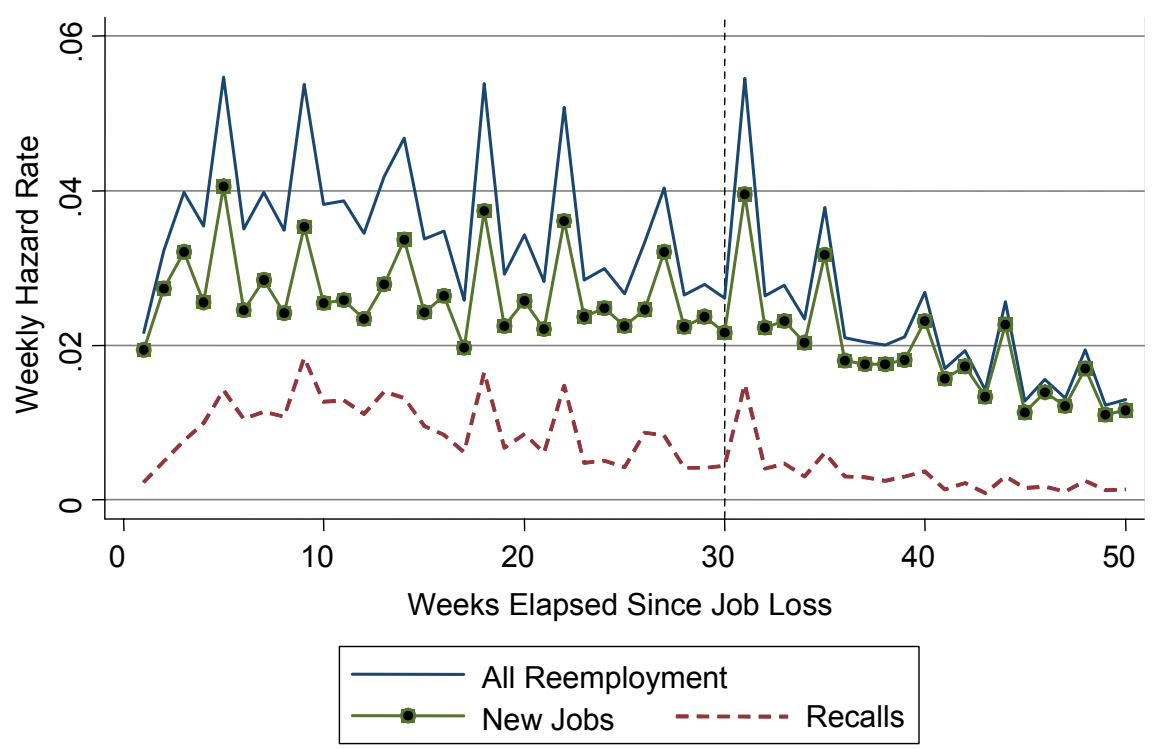

NOTE-These figures decompose the re-employment hazard into new job starts and recalls under the assumption of independent competing risks. The hazard plot for recalls treats new job starts as censored, while the plot for new job starts treats recalls as censored. All individuals in Figure $3 a$ are eligible for 20 weeks of $\mathrm{UI}$; in figure $3 \mathrm{~b}, 30$ weeks of $\mathrm{UI}$. 
Figure 4a

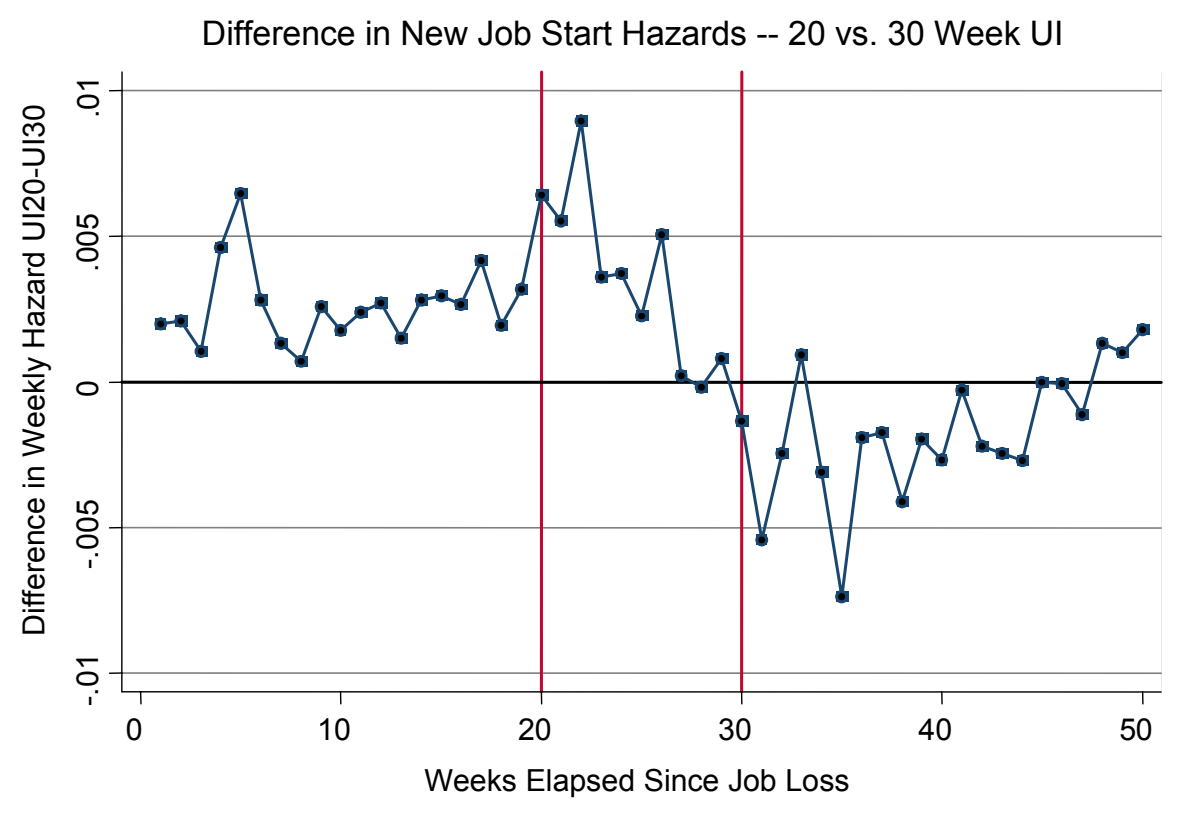

Figure $4 b$

Difference in Recall Hazards -- 20 vs. 30 Week UI

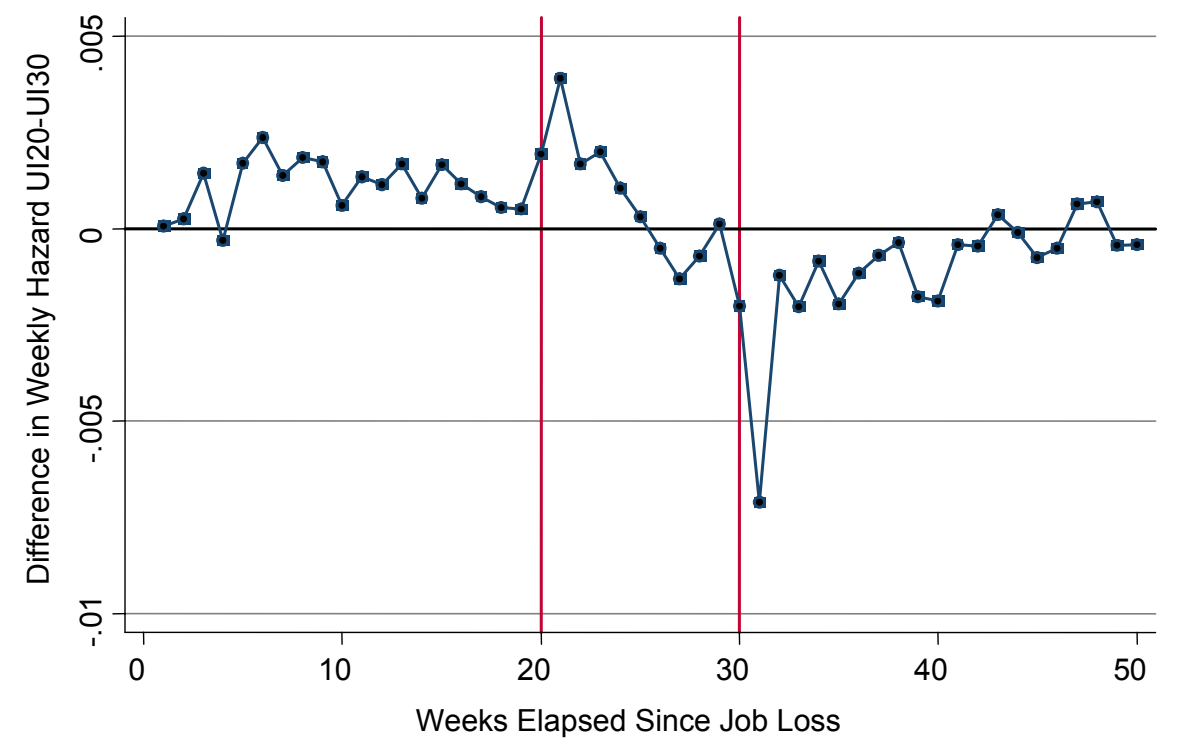

NOTE-These figures plot the difference in weekly job-finding hazards between the group of individuals eligible for 20 weeks of $\mathrm{UI}$ benefits and 30 weeks of $\mathrm{UI}$ benefits. The new job start hazard series is the difference between new job start hazards plotted in Figure $3 \mathrm{a}$ and $3 \mathrm{~b}$. The recall hazard series is the difference between the recall hazards plotted in Figures $3 a$ and $3 b$. 